\title{
Globalisation and the Diaspora: The Development Dimension in Nigeria
}

\author{
Adu, Funmilayo Modupe (Ph.D.) \\ Department of History and International Studies, Faculty of Arts, Ekiti State University, Ado Ekiti \\ *Corresponding Author: Adu, Funmilayo Modupe, Department of History and International Studies, \\ Faculty of Arts, Ekiti State University, Ado Ekiti
}

\begin{abstract}
A fact recognized by international migration scholars is the dynamic and active link of diaspora with host and home country. This is made more important by the globalization interchange. Diaspora groups are underrecognized and undervalued in the development interventions of their region of origin. This lack of recognition could be attributed to little scholarly studies in developmental interventions of homeland by diaspora, lack of recognition and encouragement by homeland government, little contact preceding the globalized advantages of technology and lack of or little appreciation of the scale, scope and impact of diaspora for developing countries (see AFFORD, 1998). It is noted however, that the scale, scope and impact of different Diaspora efforts for development will vary by a range of factors, i.e. size of the developing country in question and complexity of the challenges it faces, the input/level of adoption of globalized technological advantages and level of receptivity. In the Nigerian instance however, intensified globalized networking was noticed at the introduction of the worldwide web, interconnectivity and interchange promoted contact and financial transfers to increase the awareness and increase the opportunity for diaspora intervention advantages. In the light of this international migration becomes an important resource in assisting development.
\end{abstract}

Keywords: Globalisation, Diaspora, Development

\section{INTRODUCTION}

The dynamic and active link of diaspora with host and home country is a fact recognized by international migration scholars. The dynamics of globalization has impact in homeland and country of residence. Scholars (Oucho, 2010, Mberu, undated) have noted that, Diaspora groups are underrecognized and undervalued in the development interventions of their region of origin. This lack of recognition could be attributed to little scholarly studies in developmental interventions of homeland by diaspora, lack of recognition and encouragement by homeland government, little contact preceding the globalized advantages of technology and lack of or little appreciation of the scale, scope and impact of diaspora for developing countries (see AFFORD, 1998). It is noted however, that the scale, scope and impact of different Diaspora efforts for development will vary by a range of factors, i.e. size of the developing country in question and complexity of the challenges it faces, the input/level of adoption of globalized technological advantages and level of receptivity. This is not to say that other developmental efforts are invaluable but the focus of this work is on the diaspora efforts in the important purpose to complement other developmental activities in elimination of poverty and to promote development through direct civil society and intervention through governmental process.

In this paper, this research took a brief look at globalization and migration, diaspora and the globalization advantage. Besides, this work discussed diaspora and development interventions in homeland community by focusing on the African diaspora as a generalization and Nigeria as a specific.

\section{Globalisation AND Migration}

In this paper, the term diaspora is used to describe migrants or ethnic minorities located away from their place of origin. Discussions and many of the answers to the questions raised by this work are better understood within the framework of the overarching phenomenon of globalization, a concept of the $21^{\text {st }}$ Century to describe what Iyayi (1999) noted as "a change which had made the world a small place" or a global village. 
Abimbolaet al (2004) described this as, the increasing interconnectedness between national economies and the integration of people around the globe into a world society. He further explained that, it is concerned with the opening up of new imperatives for investigating power linkages between thought and action, knowledge and being, structure and process(ibid). Globalization is the process in which the elimination of national barriers and the expansion of international transactions are being carried to the ultimate conclusion, a process fuelled by and resulting in increasing cross-border flows of goods, services, money, people, information and culture (Martin Albrow, 1996, Held et al, 1999). Scholars agree, it is greater interdependence and global integration in which diverse peoples, economies, cultural and political processes are increasingly subjected to international influences, and people are aware of such influences in their everyday lives (Guillen, 2001, Petrella, 1996, Abimbola, 2004, Midgeley, 1997).

It is also the awesome changes resultant of or mandated by the revolution in technology, the collapse of boundaries between different worlds, expanding connectivity and interactions and interdependencies. The multiple meaning and linkages of the ideology of globalization is an accepted thing. Cox (1996) observed that it appears to be closely and loosely associated with neo liberal ideals and with technocratic solution to economic reforms and development (Menichgel, Evans, 1997). Further linkages can be traced to cross-border advocacy networks and organizations defending human rights, the environment, women's rights, or world peace (Kechi and Sikkink, 1998, Guidry et al, 1999). It is noteworthy that the usage of the word by the press, as noted by Hirsch and Fass (2000), appears associated with multiple ideological frames of reference, which include financial market, economic efficiency and negative effect on culture and society.

The concept of globalization, in divergent schools of thought, accedes to a range from the liberals to historical structuralism and realist school of thought. It is important to note the increasing pace of global interventions at the instance of the realist school which arrogated a most powerful influence to the powerful developed states of the world (Boyer and Drache, 1996, Hirst and Thompson, 1999, Iyayi in Adepoju and Anie Van Wiel, 2010: 16-35).

Globalization is claimed by scholars to have both negative and positive implications for states and individuals in the international system. Amongst the important changes or development that has great impact on human society, globalization is traceable to decades and centuries beyond the now. It is noted as the expansion of capitalist values and ethics which can be categorized into three phases:

- $400-1850$

- $1850-1960$

- 1960 to date

Iyayi (cited in Adepojuet al, 2010) quoted Tomlinson (1999:2) "globalization refers to the rapidly developing and ever-densening networks of interconnection and interdependencies that characterize modern social life" McGraw reiterates, "Nowadays, goods, capital, people, knowledge images, crime, pollutants, drugs, fashions and beliefs are readily now across territorial boundaries. Transnational networks, social movements and relationships are extensive in virtually all areas from academic to the sexual..." (McGraw, 1992: 65, 67) (Cited in Iyayi, 2004:24).

Iyayi (2004) also emphasized "the fact that globalization resides in the expansion of a dominant but particular form of economic and hence political and cultural practice which means that it (had) been present throughout human history (Iyayi,2004:25). In line with this he quoted Eskor Toyo (2001:53) as: the global economy from the ancient Egypt five thousand years ago to the present day has always had a structure, which determines distribution of the possibilities, benefits, and penalties of trade and foreign investment. This structure changes from epoch to epoch. As it does, so do the fortunes and misfortunes of nations in trade: History clearly show that some kinds of anarchy are frequently better than some kinds of trade in a predatory world.

The globalization of capitalism is the globalization of modern slavery (cited in Iyayi, 2004). The first epoch that provided the foundation from which other phases expanded is the mercantilist and the slave trade periods; the maximization of the production of plantation crops especially sugar cane in the "New World". The huge profit from the era created the second phase of capitalist expansion in joint stock companies and monopolies. The second world wars and acquisition of colonies were resultant of this era. The colonies became satellites for the exploitation of raw materials to the metropolis, the 
third phase started with the World War II through the internationalisation of institutions such as the IMF/World Bank, London Club, CIA, WTO, Ford Foundation and Multinational organizations like Shell Petroleum (Iyayi cited in Akanni, 2004). With the end of the Cold War in 1991, states became the major apostle of Globalization.

The goal of globalization is to increase material wealth, goods and services through international division of labour, a process by which regional economies, societies, and cultures have become integrated through communication, transportation, and trade; also the integration of national economies into the international economy by direct investment, capital flows, migration and trade, the spread of technology and military presence (Akanni, 2010:2). It is noteworthy that globalization is driven by a combination of economic, technological, socio cultural, political, and biological factors. It is the transnational circulation of ideas, languages, or popular culture through acculturation (Iyayi, 2004 cited in Adepoju, 2010).

Globalization advantages have led to increased migration and a resultant transnational networking across state boundaries. These have created a new dimension to the needs of state, the processes of state development intervention being influenced more and more by external contacts and negative and positive outfalls bringing in a new dimension to development interventions. Technological development continues to affect several aspects of the state, and one important area, which is the focus of this work, is the contribution of the diaspora.

\subsection{International Migration}

The wave of international migration across the globe is increasing daily and the impact of such migrations on host and home country has become a continuous quest of research inquisition. The World Bank cited Caglar and Maurice,

Over the centuries millions of people have migrated - despite the physical, cultural, and economic obstacles to other lands in search of better lives for themselves and their children. Currently, the number of people living outside their country of birth is estimated to be over 180 million or 3 percent of the world population. (World Bank, 2006 cited in Caglar and Maurice, 2007:1)

Adepoju (2010:4) recorded that "Africa is often portrayed as the continent with the most mobile population in the world". This conclusion is historically based as records of migration dates back to the trans-Saharan trade and the trans-Atlantic slave trade. The focus on migration studies is relevant for policy making and the development interventions of both the country of origin and host country. What is the extent of contact that Nigerians abroad maintain with their families and communities back home? How involved are they in the economic, political and other issues affecting their country and what is the governmental attitude towards migration? Does the country benefit from migration advantages? These questions provide us with necessary curiosity for this research.

This research will thus contribute as one important source to finding solutions to Nigeria's development problems. Reasons that have been adduced for migrations from Nigeria vary from demographic pressures, political instability, bad governance, low economic performance, and high poverty levels, search for the Golden Fleece and social pressure and persistent ethnic conflicts. Adepoju noted that,

Rapid population growth places tremendous strain on Africa's development as the disparity between labour force growth and job creation creates migratory pressures by generating high rates of under and unemployment. Political instability resulting from political, religious and ethnic conflicts is another strong migration determinant factor. . . widespread poverty and human deprivation, and the deterioration of the well being of the vast majority of the Nigerian population have created a sustained pressure for labour emigration (Adepoju, 2010:4)

Estimated population of Nigerians abroad have ranged from 0.6 million (according to OECD statistics) and 20 million (the Ministry of Foreign Affairs of Nigeria). This variance in the current debate on migration is to Adepoju (2010) often related to the popular definition of who is classified as a migrant. This important reason made Adepoju to differentiate between regular migrants, and the "so called" Nigerian Diaspora" - This last group he includes as the second - and third generation Nigerians who were born overseas and are foreign passport holders, but still maintain close ties with 
their families at home, and send remittances regularly. Adepoju also noted the United States and United Kingdom/Britain as the dominant destination countries for Nigerians.

A dimension of feminised migration was also recognized by Adepoju when he submits that,

A common view, currently, is that once the inflow of migrant labour was stopped by receiving countries around the mid-1970s, family reunification became the major mode of admission to foreign countries, and consequently female migration became dominant. But studies also show that a growing number of women now migrate for economic rather than family reasons. This is due largely to the fact that there is an increasing demand for service, provided by women working for example, as domestic workers, nurses, teachers, and even as sex workers (Adepoju,2010:6)

It is important to note that Nigeria's position in the past, Laissez-faire approach - which is neither to promote nor actively to stop migration, is due to the large relative number of immigrants and emigrants. This however needs to change as a large volume of development advantage is being lost due to this neglect. Problems arising from irregular migration have also intensified the negative aspect of smuggling and the trafficking of human beings. The intensification of studies in Nigeria's attempt at strengthening the synergies between migration and development is important in light of the intervention of globalisation.

In 2007, Nigeria launched its national policy on migration which following a holistic integrated approach towards migration, puts centrally the issues of the impact migration can have on the development agenda of Nigeria. A trend of irregular migration, it is believed could result into the reduction of development benefits of migration. This is because illegal migrants are vulnerable and exploited. They are not able to unionise, and are exploited by unscrupulous employers. Dangerous routes are employed by this group to the detriment of the nation as loss of life of highly skilled labour migrants desperate for the greener pasture is the recorded trend. It is important to note that movement of such large numbers of people create important economic benefits to the migrants, their families back home, and their adopted countries (Caglar and Maurice, 2007:1). The economic importance of such migration, for example, is noted by them. According to them:

Remittances now constitute the largest source of foreign capital for dozens of source countries. At the same time, migration creates social, cultural and political challenges that can create strong opposition and overwhelm any rational policy debate in source and destination countries (Caglar and Maurice, 2007:1)

The rapidly growing importance of political, economic and social advantages of migration has attracted attention in several instances. The United Nations Secretary General and other governments launched a global commission on international migration in 2003 which concluded its work in 2005. A UN High level Dialogue on international migration and development was held for the first time in September 2006. Such works were with the objectives of providing some analysis and empirical evidence to serve as the foundation for expanding understanding of the determinants and effect of international migration and remittances and to identify policies, regulations and institutional arrangements that lead to superior development outcomes (ibid: 2)

The issue of return migration is also important to development intervention especially in order to benefit from human, physical and social capital acquired during their citizen's stay in destination countries. Essentially, migration contributes positively to development. Important areas for analytical perusal are the brain drain with primary interest areas on health and education, remittances from migration, the return migration of skills (brain gain) and diaspora linkages. Brain drain has a negative impact of loss of skill to migration countries, educated citizens and skilled personnel in search of better income migrate to the detriment of their home country, resulting in shortage of skills (OECD: Organisation for Economic Co-operation and Development).

The rates at which such skills are lost are usually higher than they are replaced. In this wise, Adepoju (2010) noted that Africa is most hit in the loss of educated personnel to more developed regions of the world. In this wise, he emphatically stated that:

In relative terms, Africa is the continent exporting the greatest number of educated and highlyeducated migrants. And over the past thirty years, West Africa has been the most important 
source of brain drain from Africa. As the economy of Nigeria declines at the end of the 1980s, many highly-trained Nigerians in particular those from the health sector - joined the stream of skilled migrants to overseas destinations (Adepoju et al, 2010:10).

This idea is corroborated by Akanni (2004) who cited the National Policy on migration record that, by 2003, almost a third of Nigerian medical doctors had emigrated. Also, Nigeria ranked first among African countries (and fifth globally) with the largest number of nurses moving to OECD countries. This is a hindrance to the realisation of the health-related target of the United Nations Millennium Development Goals (MDGS). Scholarly works such as Akanmu (2010) agree that if better managed, this brain drain could be changed to brain gain or into brain circulation.

The economic doldrums of the 1980s also resulted in the migration of academics to seek better paying opportunities. Also students began to seek admissions to universities and higher institutions of learning outside the country, with the belief that this would enhance their job opportunity with the tendency of a desire not to return. Nigeria is noted as the largest supplier of African students to western universities with substantial annual financial drain of about 2 billion dollars as fees. The gap left by experienced academics in doing research for the development and training of the man power results in accentuation of poverty and further intensify migration pressures (Adepoju, 2010:11).

It therefore becomes relevant to consider the return flow of migrants' remittances to their home countries. The World Bank recorded a doubling of worldwide monetary remittance from 2004. In this wise, the level of remittance in 2007 was more than double the global development aid to developing countries from all sources (Adepoju, 2010:11), also the Central Bank of Nigeria record indicate remittances through the banks by diaspora citizens to have increased from US dollar 2.6 billion in 2004 to US dollar 19.2 billion in 2008. This record does not include unofficial remittances. To buttress this, it is recorded that a study funded by the UK's Department for International Development (DFID) on the UK Nigerian remittance corridor insinuated that at least 50 percent of the remittances to Nigeria are sent through non-official channels. An advantage gotten through the method is in funding of migrant's families in the homeland. Adepoju noted that:

While remittances are generally used by migrants' families to meet daily needs such as food, health, and education, they are increasingly also invested in improvements to homes, the purchase of landed property and entrepreneurial activities. By raising the total purchasing power of the recipients, there is a macro-economic ripple effect which gives rise to a need for government (at all levels) to identify ways of maximising the developmental effects of remittances. As a source of additional income, remittance can promote economic development and poverty reduction in the places of migrant origin (Adepoju, 2010:12)

Return migration is an essential area for development intervention. Encouragement by host country and international organisations are noteworthy in this direction. Return migrants take advantage of capital accumulation and acquired skills abroad. The International Organisation for Migration (IOM) has a programme making it possible for professionals in the diaspora to return home temporarily, to make their knowledge and expertise available in their home countries (See Akanmu, 2010, Nwosu, 2000).

The advantages of globalisation has intensified the usefulness of diaspora in political advocacy, charity and cultural exchange, hometown associations in host countries assist new arrivals to adapt and insert themselves into labour markets, as well as maintaining linkages with home. This promotes linkages even with later generations of migrants who might have become further acculturated without these advantages. This dimension is for further and future research in identity creation amongst the diaspora. The formation of professional, ethnic and religious associations by Nigerians living abroad is a major contribution to migration and development interventions. Poverty reduction, sustenance of democracy, political stability, and socio-economic development amongst others are areas of focus in this wise. The Nigerian government is not exploiting sufficiently the advantages of a deeper engagement with the diaspora.

It is noteworthy that members and organisations of the diaspora can increase and encourage networking with home government for development advantages. The Nigerian house committee on diaspora and the evolution of official national policy towards the Nigerian diaspora exploits government diaspora partnership to maximise the potential benefit of mutual advantages. Such organisations include the Nigerians in the Diaspora Organisation and the Nigerian National Volunteer 
Service. An assessment of the level of diaspora intervention in the country's development since the establishment of official national policy and in the last decades is our focus of interest. This work also addresses factors that influence in particular globalisation or the influence of technology on the intensification of involvement by diaspora actors on development strategies.

Volunteer remittances scheme and sustainable return migration are essential areas to increase development intervention. Does Diaspora benefit from the advantages of globalisation, especially as it concerns development interventions? This is a case for the argument in this sub section. The diaspora is a growing body of influence in the international system. Its impact and influence on the homeland is an important resource for the development of the state. Globalisation is an important instrument in this dimension. Mabohunje (cited in Adepoju, 2010:viii) commented that globalisation could be said to be the most challenging development in recent times, a phenomenon described as a process which in part is the product of the tremendous impact of advances in information technology on global relationships and the global extension of the capitalist mode. He insisted that:

The phenomenon has been described as a process which is in part the product of the tremendous impact of advances in information technology on global relationship and in part the result of the global extension of the capitalist mode of production on the free market economy with its enormous wealth creating potentialities (Mabohunje cited in Adepoju, 2010:viii)

It is interesting to note that since the 1950s, there was a significant development in transport technology (jet engine) and important innovations in information technology which began to drive the global economy and other aspects of society (Rourke, 2007, Mabogunje, 2010, Adepoju, 2010, AFFORD, 2000). Important innovations in the productive sector are the computer; photo copying machine and the consumer sector are the transistor radio, the television audio/video and telephony. The impact of the Global System for Mobile communication (GSM), the Global Positioning System (GPS), Satellite imaginaries and other remote sensing equipment.

These technologies have improved contacts presenting a must visit picture of happenings across the globe and temptations and lure of better life for the youth in more developed areas of the world. It is in this wise that Mabogunje noted that:

The world has witnessed a continuous cascade of innovations in all of these areas which have the interesting effect of presenting to even the most remote and isolated rural areas of developing countries ... pictures of the existing living standards and employment opportunities in the more developed regions of the world (Mabohunje cited in Adepoju, 2010:viii)

He further noted that:

And the GSM revolution has meant that even the poor can now talk and communicate directly with relations, friends and acquaintances that have made it to those regions. Thus, if in the past, rural-urban migration can be conceptualised in terms of the "bright-light attraction" of elites, it is now possible to configure in the same terms international migration from developing to developed regions of the world. (ibid, xiv)

From our historical trace of globalisation we noted that historical diaspora has had high influence on the emergence and continued existence of the concept of globalisation and the impact of the term and its usages. It is argued that although the current epoch does arguably display some distinctive features, globalisation itself is not new from the earlier centuries, the mass emigration of peoples through the Trans-Atlantic and Trans Saharan trade route ensured some level of contacts and it was the freed slaves in London such as OlaudahEquiano and OuobnaOttobahCugoano who formed themselves into the sons of Africa to campaign for the abolition of slavery. It is important to note that earlier researchers have concluded that such activism in the Americas and in Britain amongst others foreshadowed the commitment of Africans in diaspora to Africa's development.(ibid) As Fryer (1984) recorded,

These eighteenth century African activists contributed to policy, they educated and informed public opinion, they advised those in the legislature, tasked with steering important laws banning the slave trade through the British parliament. (Fryer cited in AFFORD, May, 2000).

Globalisation has become an interesting phenomenon because of an important feature, the rapid flow of capital to what investors consider to be the most profitable centres of production. In the earlier 
centuries, people were forced into slavery or encouraged (indentured labour) to migrate to where the work was. Stalker (2000), however, argues that globalisation with efforts to move products rather than people will intensify migration pressures for the future. In line with this, Stalker argue that; "the flow of goods and capital between rich and poor countries will not be large enough to offset the needs for employment in poorer countries. He further noted "instead, the social disruption caused by economic restructuring is likely to shake more people loose from their communities and encourage them to look abroad for work." (Stalker, 2000:62-63)

Other considerations encouraging migrations are demographic changes in wealthier countries, conflict, human rights abuses and natural disasters (wars, persecution, drought, famine and floods etc.). The geometric increase in migrant flow (the total number of migrants around the world now exceeds 120 million people, nearly double the 75 million in 1965 and that the number continue to rise (Stalker, 2000:63) is an important reason to study the impact of migrants on home development especially with globalisation input.

Globalisation has also led to the formation of transnational communities. It has resulted into the building of networks, and social bridges across borders, familial economic, social, organizational, religious and political. Transnationalism is an extended ideas of Diaspora.(ibid) Pires Hester used the concept "bilateral diaspora ethnicity" i.e. "the strategic use of ethnic identification with an original overseas homeland to benefit that homeland through relations with systems and institutions of the current actual homeland (Hester, 1999:486 cited in AFFORD, 2000:4).

Green (1987) recorded that, transnationalism is a process "whereby trans-migrants forge and sustain multi-stranded social relations that connect their societies of origin with the societies of settlement. Consequently, they build social fields that enable them to maintain multiple relationships in familial, economic, social, organisational, religious and political - that span borders." (Green, 1987)

Importantly, studies of diaspora population have usually focused on either the sending or receiving side of the migrant cycle. Pires Hester (Hester, cited in AFFORD, 2000) (and also in AFFORD, 1999:485) insists that systemic study of the diaspora relations and networks linking or binding the members of a diaspora with its ancestral homeland is a more recent occurrence. They cited cases of the fascinating autobiographical details of the tireless $18^{\text {th }}$ century freed slaves and abolitionist activists, to explain the ties that bind. Anthropological studies of internal migrations identified the concept of trans-local societies but the idea is newly migrated into diaspora studies.

There is a more recent (within the century) pattern of migration and rapid improvement in communications technology creating a favourable condition to maintenance of diaspora ancestral home links. Crucial to the impact of globalisation on migrations is the brain gain advantage which will result only from a consciously managed system of diaspora contributions to the development of the state.

The profit from the slave trade financed the industrial revolution in Europe which was both a technical revolution and a revolution in the types and quality of products produced (Akanni, 2010:31). Iyayi (cited in Akanni, 2010:49) emphasised that a technical revolution provided the capitalism of the period with the superior arm for world conquest and by 1940, another revolution in technology was under way-driven by the $2^{\text {nd }}$ World War, a competition between the Soviet Union and the United States in technological development. The third phase (which is our focus of interest) started around 1985. This is referred to as the third period of globalisation and is majorly the revolution in information technology and it remains a major force in driving the globalisation process, much as scholarly argument focus on the exploitative advantages and the globalizing mono politics, imperialistic capitalist interest that seek to subject life to the control of its market forces in the interest of the imperialist circles. This work argues in favour of a direct and frontal solution to brain drain from the perspective of a managed (both by diaspora interest and governmental exploitation) of this technological advantages to encourage and promote the development of the state (migration origin of diaspora). Iyayi has observed that globalisation impacts upon a country only in the direction that is desired by the leaders of the country (Iyayi in Akanni, 2010:49)

Cohen's (1997) analogy in the typology of Diasporas, classified Diaspora into five main categories viz: victim, labour, imperial, trade, cultural. 
Table1.

\begin{tabular}{|l|l|}
\hline \multicolumn{1}{|c|}{ Type } & \multicolumn{1}{c|}{ Example } \\
\hline Victim & Jews, Africans, Armenians. \\
\hline Labour & Indians. \\
\hline Imperial & British. \\
\hline Trade & Chinese, Lebanese. \\
\hline Cultural & Caribbean. \\
\hline
\end{tabular}

Cohen (ibid) noted that they are not fixed categories. He also identifies the ways that the African diaspora organisations are shaped by some factors. Such factors are; actual historical connections with home country, degree of stability in current home, degree of social inclusion in current home, level of education, degree and type of political/social consciousness etc. In the table below, he further explains these ways.

Table2.

\begin{tabular}{|l|c|c|l|}
\hline \multicolumn{1}{|c|}{$\begin{array}{c}\text { Organisation } \\
\text { Type }\end{array}$} & $\begin{array}{c}\text { Neo } \\
\text { Diaspora }\end{array}$ & $\begin{array}{c}\text { Old } \\
\text { Diaspora }\end{array}$ & \multicolumn{1}{c|}{ Example } \\
\hline Individual & $\sqrt{ }$ & & Individual sending remittances home \\
\hline Hometown Association & $\sqrt{ }$ & & Nnewi Hometown Association \\
\hline Ethnic Association & $\sqrt{ }$ & & Buganda Heritage Association, EkitiParapo \\
\hline Alumni Association & $\sqrt{ }$ & & EbikuNyaBaganda Old Budoyans Association \\
\hline Religious Association & $\sqrt{ }$ & $\sqrt{ }$ & MouridesAusarAuset Society \\
\hline Professional & $\sqrt{ }$ & $\sqrt{ }$ & Society of Bricklayers \\
\hline Development NGO & $\sqrt{ }$ & $\sqrt{ }$ & ABANTU for Development Africare \\
\hline Investment Group/Business & $\sqrt{ }$ & $\sqrt{ }$ & African/ Caribbean Finance Forum \\
\hline Political Group & $\sqrt{ }$ & & Movements for the Survival of the Ogoni people \\
\hline National Development Groups & $\sqrt{ }$ & & National Association of Sierra Leoonean Organisation \\
\hline Welfare/Refugee Groups & $\sqrt{ }$ & & African Francophone Resource and Information Centre \\
\hline Supplementary Schools & $\sqrt{ }$ & $\sqrt{ }$ & San kofa \\
\hline Virtual Organisations & $\sqrt{ }$ & $\sqrt{ }$ & Somali Forum \\
\hline
\end{tabular}

Culled from AFFORD, 2000:6.

It should be noted that, old diaspora refers to the African diaspora produced by the Atlantic slave trade: New diaspora refers to those Africans who have left Africa in the Post-Second World War or even late Post-Colonial period (AFFORD, 2000)

Other forms of Diaspora engagement are listed below:

- Person-to-person transfer of money, consumer goods, and even larger items such as cars, mainly to family, immediate and extended.

- Community-to-community transfer for constructive but sometimes for destructive purposes.

- Identity building/awareness raising in current home about ancestral home either with other members of same community or with wider groups.

- Lobbying in current home on issues relating to ancestral home either of current home politicians or visiting ancestral home leaders.

- Trade with and investment in ancestral home (including electronic commerce).

- Transfers of intangible resources such as knowledge, values and ideas.

- Support for development on a more - "Professional basis"

- Payment of taxes in ancestral home.

Source: AFFORD, 2000:6.

Ethnic relations across border are further observed by Pires-Hester (Hester, 1999:490 cited in AFFORD, 2000) as long standing remittance pattern. In this line, he argued that "the roots of bilateral diaspora ethnicity can be found in long-standing remittance patterns, gradual politicization of voluntary associations and transformed attitudes of Cape Verde towards its diaspora population" (ibid). This view is harmonised as generally true for numerous diaspora communities by Al-Ali et al (1999). 
The importance of diaspora remittance cannot be undermined as development requires funding and diaspora funding of development is a source that importantly has continued to impact on homeland. It is generally believed that remittances are important and concrete manifestations of diasporas commitment (and obligation) and connections. Bilateral remittance transfer is noted as important in a study of Cape Verde "person to person" strategy.

A 1912 German visitor reported a postman's estimate of approximately 100,000 (dollars) arriving in 10,000 - person Island of Bara; The Agency for International Development (1982) estimated that "official transfers" had gone from 10.2 percent to 18.4 percent from 1972 to 1978 , as compared to 8.7 percent to 18.7 percent for "private transfer" during the same period. The World Bank estimated in 1983 that "large emigrant remittances" raised Cape Verde's GNP per capita income from 200 dollars to 300." (Piere Hester in AFFORD, 1999:490)

Importantly, informal transfers of remittances have by passed official records of bilateral diaspora transactions. In a survey of World Bank data on Sudan, Brown (Brown, 1990) pointed to the fact that the data overlooked non-bank remittance transfers from Sudanese living in the Gulf. Records have shown (Stalker, 2000, World Bank, 2000) that the benefits of remittances to receiving economies depend on the structure of the local economies and the capacity of recipients to make productive use of these resources. For developing economies with small sizes, remittances represent a significant source of foreign exchange. Egypt, for example, is recognised as one of the top five of the remittances top partners. Community contributions have collective efforts to effect transfers and development in their region of origin (homeland).(ibid)

The Mali Diaspora in France has importantly impacted on the development of the state through community effort of diaspora settlers. Libercier and Schneider (1996) reviewed this in a citation by AFFORD (AFFORD, 2010:7).

In concrete terms, the impact of emigrants' transfers is all the more visible when it is concentrated in a single region. This is the case for the Kayes region of Mali, the home region of the great majority of Malian immigrants in France. The region benefits from the actions of immigrants associations which have managed, moreover to energise the beneficiary villages: 39 of the 42 development associations in France are also present in the villages. They have understood the need to federate, to be able to act on a larger scale in the district or regional level. (Libercier and Schneider, 1996:38) (AFFORD, 2010:7).

Libercier and Schneider (1996) further noted/recorded that;

Many associations have been formed, grouping all the 15 to 40 villages of a district. Among other things, they contributed to the development of hydraulic networks to improve agricultural production. Seventy percent of the immigrants in France who stem from the Kayes region are active members of their village associations over a period of about ten years, they financed 146 projects for a total budget of 19.4 milion French Francs, they contributed 16.6 million Francs from their savings, the remainder 2.8 million Francs being contributed by NGOs with aid from international donors. Thus, 64 percent of the infrastructures in the villages of the Kayes region are attributed to the migrants. (Cited in AFFORD, 2000:8)

\section{DIASPORA AND DEVELOPMENT INTERVENTIONS}

Several studies of African diaspora remittance contribution (Adepoju, 2000, 1997, Adepoju and Arie Van der Wiel, 2010) reveal a concrete evidence of the fact that much of Africa's engagement with its diaspora is concrete and constructive. The negative dimension to this fact is the funding and fuelling of conflict back home. The capacity of Diasporas to engage in development interventions is reliant on several factors which are listed as: desire, capacity and environmental. These three groupings can also be further looked at from the economic, political and social dimensions. In a study of Eritrean and Bosnian refugees, capacity and desire to participate in reconstruction in their home countries are considered the economic, political and social factors (Ali Aliet al, 1999).

Table3.

\begin{tabular}{|l|l|l|l|}
\hline & \multicolumn{1}{|c|}{ Economic } & \multicolumn{1}{c|}{ Political } & \multicolumn{1}{c|}{ Social } \\
\hline Capacity & $\begin{array}{l}\text { Employment } \\
\text { Savings }\end{array}$ & $\begin{array}{l}\text { Secure legal status in host } \\
\text { country }\end{array}$ & $\begin{array}{l}\text { Freedom of movement within } \\
\text { host country }\end{array}$ \\
\hline
\end{tabular}




\begin{tabular}{|c|c|c|c|}
\hline & $\begin{array}{l}\text { Access to welfare and pensions } \\
\text { from home country } \\
\text { Access to welfare and pensions } \\
\text { from host country } \\
\text { Access to information } \\
\text { Access to Banking facilities }\end{array}$ & $\begin{array}{l}\text { Positive attitude of host } \\
\text { government and population } \\
\text { towards Ethnic national diasporas } \\
\text { Political integration of diaspora by } \\
\text { home government }\end{array}$ & $\begin{array}{l}\text { Gender equality } \\
\text { Successful social integration in } \\
\text { host country } \\
\text { Place of origin in home country }\end{array}$ \\
\hline Desire & $\begin{array}{l}\text { Financial stability in host } \\
\text { country } \\
\text { Economic incentives or lack of } \\
\text { disincentives for remittances } \\
\text { and investment in Home } \\
\text { country } \\
\text { Economic stability in home } \\
\text { country }\end{array}$ & $\begin{array}{l}\text { Secure legal status in host } \\
\text { country } \\
\text { Non alienating circumstances of } \\
\text { flight } \\
\text { Positive attitude of home } \\
\text { government towards diaspora } \\
\text { Political stability in home } \\
\text { country, lack of ethnic/religious } \\
\text { discrimination in home country }\end{array}$ & $\begin{array}{l}\text { Links with family and friends in } \\
\text { home country } \\
\text { Links with friends and family in } \\
\text { other host countries } \\
\text { Integration within the diaspora in } \\
\text { the host country } \\
\text { Positive attitude towards home } \\
\text { country } \\
\text { Desire to maintain "national } \\
\text { consciousness" }\end{array}$ \\
\hline
\end{tabular}

Source: ( AliAliet al1999 cited in AFFORD DOCUMENT, 2000:8)

Diaspora grouping could be National, which could create a "national consciousness" for national reconstruction of nation states; the more specific of this consciousness focuses on the village, the clan, the family, the school, the church and so on. This, according to AFFORD (2000:8), translates to a probability of low level national (state) consciousness but still very active in group conscious effort towards homeland". The diaspora need not necessarily identify with the nation-state to at least potentially be active and contribute in some way, but a positive attitude by the state to the diaspora grouping is desirable". A sense of insecurity has been identified as an important factor and a key driver monitoring a removed people to invest "back home". In this wise, McNulty and Lawrence (1996) reveal that the strength of hometown association in Nigeria can be attributed to the experiences of conflict destructions and disruptions. (McNulty and Lawrence, 1996:24) They pointed out that:

The strength of hometown associations in Nigeria can partly be attributed to the trauma of the civil war which taught people the importance of having a secure home base in the event of trouble in the place where they found themselves . . . likewise many of Africa's diaspora may start out as refugees habouring every intention to return and are therefore focused on paving the way for their return. The more hostile the host environment in this case, the more appealing home remains (AFFORD, 2000:9)

Ali Aliet al (1999) cited in AFFORD, 2000:9) further explained that:

The anecdotal evidence suggest that those most in the diaspora who are most marginalized, un-or underemployed sometimes may actually be the most frequent remitters home, partly as a form of pension investment pending their return, but also because their families back home may be most in need.

A summary of important key variables to the implication of diaspora and development in the context of globalization can be understood with an assessment of the highlighted AFFORD categories which are:

- Form of Diaspora organization

- Host and home state-diaspora relationship (both ways)

- Information and communication flows between home and Diaspora

- Local conditions in developing region that necessitate charitable interventions or create ideal conditions for Diaspora investment

- Circumstances of Diaspora in host environment

(Source: Afford Paper, 2000:12)

The contribution of diaspora to development is also important as the World Bank (2000:18) notes, "Cross-border migration, combined with "brain drain" from developing to industrial countries will be one of the major forces shaping the landscape of the $21^{\text {st }}$ century

It is no wonder that in its November 1997 white paper on International Development, Eliminating World Poverty: A Challenge for the $21^{\text {st }}$ Century, the DFID committed the British government to "build on the skills and talents of migrants and other members of ethnic minorities within the UK to promote the development of their countries of origin" (AFFORD PAPER ,2000). The value of 
Diasporas actual and potential contributions to development is a concrete fact that needs to be recognized and exploited.

In today's era of globalization, access to and effective use of Information and Communication Technology (ICT) is central to the effectiveness of a diaspora contribution to development. Previous researches on the African Diaspora and remittance flows to Africa have generated inconclusive findings, concentrating on the sources of resources and neglecting their effects on the destinations where their impacts are directed. Adepoju has suggested that African countries need to incorporate the contribution of their diaspora and remittances in national development planning and programmes. (Adepoju, 2010:161)

As development scenario is changing, it is important to absorb and understand the mobility of people in the new context of technological progress especially in the domain of ICT and transport facilities. Digital interactive media such as internet, mobile and television provide a new interactive space for the diaspora and transnational communities to experience and connect life across borders. Adepoju reiterated the fact that ICT mediated interaction have socio-economic aspect that deeply influence society. He (Adepoju, 2010) further noted that Diaspora in the age of internet, are seen as resources that accumulate human, financial and socio-political capital for the development of their home communities (Adepoju, 2010:161-162).

In opposition to the old brain drain ideology of the 60s and 70s, diaspora in the internet age are seen as resources with human, financial and social capital for the development of their home communities. The Indira Ghandi national Open University in 2011 re-affirmed that Governments and development agencies of countries of origin in many developing countries have been playing a growing role in channeling the initiative, energy, and resources of diaspora into economies and societies and institutionalizing the linkage of the diaspora to the socio-economic activities of their home countries, noting that many Asian and African countries have taken initiatives at the top level to provide institutionalized platform to facilitate the diasporas to play development role back home. (AFFORD 2000).

Financial capital accumulated by diaspora abroad is repatriated to the country of origin in the form of remittances or direct investment to benefit the home community with technological advancement. Human capital can be easily transmitted across border with the use of ICT to create opportunities in many sectors such as higher education, training, research and development etc. It is noted that these forms of human capital can contribute to the development of the home country through return skills by return migration or "virtually" by using communications technologies in the host country. It is important to note further that social capital in the form of migrant networks with links to both host and home countries can provide developing countries with access to more developed markets (AFFORD, 2000). Access can also be instrumental in orientating foreign direct investment towards the home country. Diasporas can organize themselves and form associations that are able to promote the flow of investments and knowledge to their home countries.

\section{Nigerians in THE DiaSpora AND NATIONAL DEVELOPMENT}

National Development is concerned with solving national problems and addressing pressing national issues. It is concerned mainly with the entire life and needs of citizens from the socio-economic or political context. (Ayodele, 2005:150). Aguolu (1989) in his inaugural lecture explains the concept of National Development as being broader in scope and encompassing economic growth, as one of its facets. He (Aguolu, 1989) identified that in the pursuit of economic growth, (based upon western European and North-American models of growth through technological infusion, industrialization and economics of scale), Nigeria has excluded almost $80 \%$ of its population from the process of development.

Todaro (1989), Mabogunje (cited in Aguolu, 1989) explains the development process as involving economic growth, modernization, equitable distribution of income, national resources, and socioeconomic transformation. Todaro specifically noted it as "a multi-dimensional process involving major changes in social structures, popular attitudes, and national institutions, as well as the acceleration of economic growth, the reduction of inequality and the eradication of absolute poverty" (Todaro, 189:89-90) Omotola (2010) explains Todaro's expatiation of the three core values of development to include the ability to provide as many people as possible with their basic needs or the ability to acquire adequate food, shelter, health care and protection. In a further enumeration by citing 
Ogwu (Ogwu cited in Omotola, 2010:110), he emphasized that it further entails the perception of individuals or groups of self-worth and esteem as a respected member of the society and freedom in the sense that individuals and society at large have an expanded range of choice, not only with respect to the material necessities for self-reproduction, but also in their ability to have a say in, if not to determine, the method and process by which values are allocated in the society (Ogwu, 2002:12-13).

The total involvement of the state and civil society in the process of development is acceded to by scholars (Ogwu, 2002, Todaro, 1989, Aguolu, 1999, Omotola, 2010, Lane and Ersson, 1997). It is important to note that political economists such as Ake (1992, 1981, 1996, Adedeji, 1993, Onimode, 2000, ArmatiSen, 1990) have illuminated the concept to connote capacity expansion, which is to Sen (1999) synonymous with freedom. In line with the ideals of capacity expansion, development requires adequate empowerment of the state and the society. The state and society need to adequately distil their complementary roles and responsibilities (Sen, 1999). Importantly in the process, it requires an enhanced state capacity, as well as institutional and governmental stability.

Individual members of the society can only find fulfillment and satisfaction in terms of the basic needs within this framework. Omotola (2010) believes that as a freedom, development demands great latitude of autonomy for the political community and its constituent parts, as well as for the individual members of such communities. Such instances ensure the level of popular participation, (measured in terms of the quality and quantity of participation) is highly decisive (Omotola, 2010:111).

Mabogunje A.C. (Cited in Aguolu, 1980:16) identified the internal attributes of development. In this he observes, development involves economic growth, modernization, equitable distribution of income, national resources, and socio-economic transformation. It is important to note that development connotes growth plus change and change may be social, cultural, economic, quantitative or qualitative. Aguolu (1989) thus concluded in effect that, national development incorporates economic growth as well as cultural, educational, political and social advancement of the people i.e. all the processes that are aimed at improving the quality of use of the people. This is not limited to the urban centre but must essentially permeate the rural areas.

It is important to note that many African governments neglect the rural areas, fail to create the enabling environment for successful rural development programmes. These scholars' (Aguolu, 1989, Ake, 1992, Ajayi, 2010:180, Onimode, 2000) belief is attributable to the Euro-American approach to development which equates progress with urbanization and industrial growth, poverty, disease, inequality in income, unemployment, lack of social amenities, illiteracy, (which has consistently bedeviled Nigeria) are as noted by Aguolu (1989) at their peak in the rural areas. It is ipso facto derivable that no meaningful national development programme can succeed, when Nigeria neglected the rural majority. It is important therefore to approach development from a holistic perspective, an inclusive, nationalist, and national oriented process which does not restrict efforts of development to mere economic growth.

Todaro and Smith (2009), in further explaining the implications of development, quoted Dudley Seer's posed basic questions on the meaning of development.According to them,

The questions to ask about a country's development are therefore: what has been happening to poverty? What has been happening to unemployment? What has been happening to inequality? If all three of these have declined from high levels, then beyond doubt this has been a period of development for the country concerned. If one or two of these central problems have been growing worse, especially if all three have, it would be strange to call the result "development" even if per capita income doubled. (Cited in Todaro and Smith, 2009:15).

While the United States, Britain, and other high income countries enjoyed a strong economic boom in the 1990s, Sub-Saharan Africa experienced a decline in average income. There was also an increase in the number of people in the region living in extreme poverty (less than one dollar per day). Underdevelopment pathetically is a real fact of life; it is a state of mind as much as a state of national poverty. To Todaro and Smith (2009), development must therefore be conceived of as a multidimensional process involving major changes in social structures, popular attitudes, and national institutions, as well as the acceleration of economic growth, the reduction of inequality, and the eradication of poverty. More emphatically:

Development in its essence, must represent the whole gamut of change by which an entire social system, turned to the diverse basic needs and desires of individuals and social groups within that 
system moves away from (one-to) a condition of life regarded as materially and spiritually better (Todaro and Smith, 2009:16).

The pivotal role of the Diaspora in African development cannot be neglected. From the period of the freed slaves, diaspora actors such as OlaudahEquiano, played a leading role in the abolition of the slave trade and the resettlement of Africans in the Freetown. Activists used the 1945 fifth Pan African Congress to make a clarion call for independence, the struggle against Apartheid in South Africa, and later the fight against poverty, the scourge of HIV/AIDS, Ecological control, democratic re-ordering amongst others, such for a provided rallying points for the African diaspora, and in recent times the Nigerian Diaspora.

The intervention of the diaspora can take advantage of the globalization process. Globalization and development are concepts that have continually been interwoven by scholars of the development interventions. The linkages between the two concepts are embedded in the fact of basic requisites of globalization which are integration and interdependence. Supporting national development would naturally include but are not limited to investing in business, making social remittances in the knowledge economy, influencing policies and supporting economic recovery, as well as engaging in various forms of human capacity development. All these development processes will take advantage of the globalization process.

\section{Nigerians in the Diaspora, State, Nation Building and Developmental Processes}

The new government of Nigeria at independence, anxious to transform the negative pictures of the colonial administration into positive policies, promised to work for raising the standard of living of the citizens. As a matter of top priority, they embarked on preparations of comprehensive development plans to provide a balanced economic, social and cultural progress for the state and the people. In achieving this purpose, the aim is to attain societies' economic and social plan for development and to seek to mobilize the people's energies to bring about national integration and secure a balanced nation building and development.

The crucial role of national planning ensures that the role of government and administration is coordinated towards development. The administration of development is the task of government and governance hence development administration, this is inclusive of economic, social and political development of all inhabitants. Katako (1971) quoted Guy Hunter, Development Administration involves virtually creating a new kind of economy by Government action(s) rather than regulating an economy powered by private enterprise"(Katako, 1971:411). To Katako (ibid) himself, it involves mobilizing efforts more widely throughout the mass of people i.e. creating economic opportunity at a humble level. The burden of nation building and development as a whole therefore, of priority amidst others, falls on government.

Government as used herein refers to the political class and the civil service as administrators of governance. It becomes imperative here to define our usages of state and Nation building and further clarify the ways through which the diaspora can contribute to this two in development interventions.

The process of translating policy into programmes and programmes into actual accomplishments require the full involvement of the bureaucracy. This process implies drafting memoranda to solicit capital resources and technicians from external donors, (e.g. diaspora remittances), working out a priority list of projects for implementation, interpreting and implementing the national plan, and evaluating plan implementation to maximized results and check achievements against the overall national plan goals (Katako, 1971:411).

State refers to a geographical sovereign political entity with a permanent population; a defined territory, a government, and the capacity to enter into relations with the other states as defined under international law (Montevideo Convention on the Rights and Duties of States, 1933 Article I). It can also refer to a set of social institutions claiming a monopoly of the legitimate use of force within a given territory (Max Weber, 1999) (Wikipedia, 12/8/11). AjayiKunle (Cited in Mimiko, 1995:180) explains the concept of state as having both legal and philosophical dimensions. The legal connotation is the basis of recognition in the international community. The ethical or philosophical dimension as Ajayi cited Hegel (ibid) is the actuality of the ethical ideal, in which the views of Hobbes, Locke and Rousseau's law and order, the good life and community building becomes paramount. The community building role of the state is primarily designed to harmonize the various 
necessary parts of society into a unified workable purpose of achieving national development. Ajayi (Cited in Mimiko, 1995:180-181) emphatically comments that in this important role, the state in Africa has proportionately failed to justify its existence. In this wise, he lamented the conditions of the African masses "the social conditions of the African masses, the subject of governance, are miserable and dehumanizing, such that the concept of state in the continent should without reservations be dismissed as out rightly irrelevant.

This situation of dire strait ultimately needs a solution. To make the state more relevant and to achieve its set out duty to its citizenry, the state need the assistance of its internal structures such as the bureaucracy and external support of international organizations and others such as the diaspora. External interventions of the diaspora are the focus of our research here because it is an understudied environment in the peculiar case of the Nigerian state. The diaspora when properly exploited can provide various forms of assistance for the bureaucracy's and states (i.e. the political class), in the translation of programmes into actual accomplishments and monitoring of achievements. The diaspora can have positive inputs in the success of state actualization of its pivotal role.

The word state building was originally coined to describe the construction of a functioning state, with the major focus on power enforcement (Tilly, 1975:70 cited in Wikipedia). Tilly described the advantages in Europe as follows:

"State" building provided for the emergence of specialized personnel control over consolidated territory, loyalty and durability, permanent institutions with centralized and autonomous state that held the monopoly of violence over a given population (Tilly 1975:70 cited in Wikipedia).

The task force of the Organization for Economic Cooperation and Development came out with a political science driven definition of "state building", which views the concept as an indigenous national process driven by state society relations. (Wikipedia) This inward looking view believes that countries are responsible within their geographical boundaries but can only influence, support or hinder such process in other states.

The Whaites model (based on a British panel Report) concludes that state building is primarily a "political" process rather than a question of technical capacity enhancement: a three-fold dynamic of political (elite) deals, prioritization of core government functions and the willingness to respond to public expectations. This only can bring the expected development.

In the American context, "nation building" is sometimes used interchangeably with "state building", nation conventionally refers to the population itself, as united by identity, history, culture and language (Wikipedia). In political science, 'nation building' is defined as the process of encouraging a sense of national identity within a given group of people. This definition relates more to socialization than state capacity. Nation building could be defined in an "ethnic or political sense". Nation building can be an important part of the process of state building and both can mutually reinforce each other. Building a nation connotes the cohesion of its separated parts i.e. ethnic units.

KunleAjayi (2010) opines that Nation is more operationally complex than the concept of state. Nation lays emphasis on the significance of common factors such as language, ethnicity, or heritage, sometimes religion, these common factors made Ajayi to agree with Rupert Emerson's (1970:90) submission: "The nation is a community of people who feel that they share deeply significant elements of a common heritage and they have a common destiny for the future".

The process of development concerns the distribution or dissemination of developmental initiatives and programmes. To Ajayi, a nation therefore would mean a people with commonly shared inherent attributes that make them markedly distinguishable from other groups of people. Such people collectively share identity, feeling of affinity, common history and a common destiny. Thus, Ajayi(ibid) concludes that a nation is fundamentally psycho-cultural. The geographical entity referred to as Nigeria therefore is a complex agglomeration of nations. Lack of acceptance amongst the homogenous constituents has created the narrow conception of a state-nation situation. The process of bringing about this nation state is not only important but unavoidable to oil the path of development. (Ajayi, 2010:180-181)

Nation building is the process of integrating diverse autonomous political entities in the state. Ajayi (ibid) further emphasized that it denotes a process whereby people transfer their commitment and loyalty from smaller tribes, villages or petty principalities to the large political system (Brown, 1987). 
Eliagwu (cited in Ajayi: 2010:182) further explains the possibility of transfer of "commitment" and "loyalties" from parochial levels to a larger political terrain through vertical and horizontal dimensions.

The progressive acceptance by members of the polity of the legitimacy of the central government and identification with the central government as a symbol of the nation is the explanation for the vertical dimension. While the horizontal dimension of nation building involves the acceptance of the civic body as equal fellow of the common history, resources, values, and other aspects of the state within the context of belonging, a sense of one political community. This is accommodation by the citizenry and acceptance of a central government. This is referred to as the quest for national unity and cohesion.

The Nigerian state, as a political entity is a creation of colonial fiat. Since its emergence, the country has been bedeviled by the scourge of ethno-religious and minority tensions, un-acceptance and outright conflict. Nwomeh captures this scenario thus:

Nigeria is an apt example of what is variously labeled "a plural society" a conglomerate society" or "a deeply divided society" a product of the forced amalgamation of disparate groups by the British colonial rulers, the country has a population of over 120 million people . . . Not only is the country vast in population and geographical size, but it is also a highly heterogeneous entity." (Nwomeh, 2005:275)

He further asserted that "this complex composition is further reinforced by the lopsided population distribution of the constituent ethnic groups, ranging in size from groups of less than 5,000 people to those numbering well over 15million. Religion is a further defining element of diversity. The North is mainly Islamic, the South largely Christian, while the traditional religion still flourishes in many parts of the country, especially the Middle Belt (Nwomeh, 2005:275-296).

It has been five decades of ethnic and sectarian violence, inter-ethnic rivalries, coups and counter coups, a dis-articulated economic development and marginalization by the constituent sectional groups and a civil war that almost disintegrated the country. A lopsided ethnic affinity that J.W. Spanier aptly capture in the statement below:

It was the territorialization by the colonial powers that defined the present frontiers of these nations. The western powers drew arbitrary lines on a map, often straight through tribal or ethnic boundaries, and then imposed a single administrative and legal structure upon the territory. All who lived within this structure were treated as if they belonged to a single nation (Cited in Ajayi 2010:183) The catastrophic effect of this lopsidedness can only be understood within the context of Nweke's submission that:

One of the most striking characteristics of Nigeria is its singular ethnic diversity, a demographic tapestry woven of more than 200 different ethnic groups, where except for the effects of migration are often geographically homogenous and often coincide with linguistic, cultural and religious groupings (Nweke, 1994,:3)

Nwomeh (2005) asserts that this variegation raises fundamental problems of how the various segmental cleavages will be equitably represented in government, how the resources of the nation will be distributed, and how to promote national integration. All these can be assisted from the wealth of experience that the diaspora are able to harness from their country of residence. The advantage of cohabitation and unity beyond homeland diversity (between Ibo, Itshekiri, Bariba, Igbira, Yoruba etc) in diaspora, cohesion of alliances formed in their country of resident could create a prototype for the homeland to follow. This unity which could be strengthened by intermarriage could after some generations, impact positively on the unity of the homeland state. (Nwomeh, 2005:273)

The foundation for good governance i.e. integration of ethnic groups is relevant. Unity, rather than diversity is essential, civil society building of bridges to dilute power and create acceptance, sustain peace, self-help development and accountable governance and sanctions on bad leadership would assist the country to move forward.

In the processes of development, the ways in which the policy makers can engage with diaspora groups are not always straightforward. This is because there is a lack of conceptual clarity about who belongs to the "diaspora", because this can encompass anyone from first generation migrants to 
people whose relatives migrated several generations previously, but who nonetheless still identify with their "homeland" to include current migrants as well as persons who no longer have citizenship status in their 'home' country but who still retain links there. The inclusive diaspora definition in this group is quite heterogeneous and could require that the policy makers attempt to identify groups that have a genuine interest in contributing to development efforts in their country of origin. (Migration DRC, Sussex Centre for Migration Research, University of Sussex).

It is important here, that policy makers are careful not to assume that the interests and agendas of Diasporas are consistent with those of home country populations, as this may vary considerably (Development Research Centre Migration, Globalization and Poverty, Briefing No 19 Aug. 2009). Governmental engagement with diaspora groups to promote development requires policymakers in the North and South to re-conceptualize development initiatives in ways that can take advantage of the transnational connection that diaspora groups possess. (Diaspora Research Centre, 2009).

Studies of overseas Chinese Diasporas noted their heavy involvement in investing in their home countries. It is noted to have about 70 percent of China's foreign direct investment between 1985 and 2000, assisting in the fuelling of China's rapid economic growth over this period. The Indian diaspora, were also key to the growth of the country's information technology sector (IT) in the 1990s. It is recorded that members of the Indian diaspora, who held senior positions in United States companies were instrumental in lobbying for the outsourcing of IT contracts to India (Diaspora Research Centre, 2009). It must be noted that the Indian and China examples were no magic. They both involved the coalescence of favourable conditions at home and within the diaspora which cannot be easily replicated without commitment.

Essentially, it must be noted that diasporas cannot create the conditions for such large scale growth on their own, and their desire to contribute must be matched by cooperation in "home" countries. This at present is lacking in the case of Nigeria. Processes of diaspora involvement in development in their "homeland" are through collective investment in community projects through hometown associations. Examples of the types of projects funded by diaspora organizations in their home countries include literacy programmes, hospitals, schools, roads, plumbing systems and internet cafes. In the example of Ghanaian hometown association, in the UK, the rationale for such philanthropy is a complex example. Ghanaian members of hometown associations (first generation migrants) have empathy to improve the living conditions of those back home (ibid). This is a major reason why the scope of these associations' contribution to development varies widely from one to another, and according to the size and wealth of the associations' membership.

Transnational linkages facilitated by Diasporas have opened up a number of possibilities for the exchange of ideas, and also return or circular migration by migrants or expatriates. The Alb-Shkenca Forum is noted as a transnational network of Albanian academics who reside both inside and outside the country. The forum searches for solutions to problems faced by Albanians and looks for ways to promote science and technology in that country. Return migration is heavily impacted upon by transnational linkages-which may in turn have positive implications for development. This is positively reflected in the case of Ghana and Cote D'Ivoire where family close transnational contact have resulted in return migration to establish own small businesses. This was not necessarily the case in the research on Tanzania and Cameroun. (African Diaspora Policy Centre, 2009).

The receptivity and development advantages might mean that some 'homes' (Country origin of migration) are better placed to take advantage of global connections than others. This could be attributed to homeland country policies. Country of origin governments can pursue policies with a view to strengthening their relationships with Diasporas.

- A shift in some countries from seeing migrants as "traitors", to seeing them as "heroes."

- Protecting migrants who are abroad, or encouraging diaspora communities to retain ties with their country of origin e.g. provision of consular services and other support for emigrants who are abroad, and allow citizens to vote in home elections, whilst they are outside the country.

- Some "home" (sending country) governments also promote national or regional culture in host countries, in a bid to re-assert cultural ties between diaspora communities and the homeland, and support the creation of diaspora organizations.

- Some countries have introduced dual citizenship programmes for expatriates. 
Source: African Diaspora Policy Centre, 2009

Other policies have directly promoted the encouragement of diaspora involvement in development in the areas of philanthropy and investment, through the identification of potential development projects for diaspora to invest in issuing special bonds targeted at diaspora members or offering bank accounts with favourable interest rates for members of the diaspora. Essentially also, a number of countries have taken steps to bolster networks of skilled diaspora, creating the potential for the exchange of skills and ideas through temporary or even "virtual" return migration. Such are examples of West African countries that have held congresses or other meetings in order to seek the input of the diaspora on their national development plans.

A study of the Philippines has shown what advantages can be accrued from the positive policy attitude of the home government to diaspora input. In an analysis of the Philippines diaspora policy, it was noted that with a fifth of the country's workforce based overseas, the country had no option than to pay particular attention to policies related to its Diaspora. A welfare fund for migrants was established, financed through fees paid by migrants going abroad, to provide death and disability insurance, health insurance, education for children left behind, or credit. The Philippines provided pre-departure training for migrants and signed about 20 (twenty) bi-lateral agreements with receiving countries in order to secure a measure of legal protection for migrant workers overseas, and provide a range of consular services to migrants abroad (ibid).

By 2003, the country had introduced legislation that allowed expatriate Filipinos to gain dualcitizenship status and extra-territorial voting rights. There is the 'national hero month' during which it confers awards on accomplished expatriates. The Commission of Filipinos Overseas (CFO) assists Filipinos who have lost their citizenship whilst overseas to regain it (especially female divorcees). The CFO publishes a newsletter "Filipino Ties" which keeps migrants abreast of happenings at home, updating on new legislation, and programmes relevant to migrants (ibid).

Through the intervention and partnership of home countries, host countries can embrace policies to play an enabling role in removing barriers to Diaspora's joint effort in development of homeland. In this wise, it is noted that, policy management is needed to avoid conflict of interest between Diasporas, sending countries and host countries. A good example is the establishment of the OXFAM Novib (a Dutch government funded organization with the support of the Ethinion governments) which focused on undertaking capacity-building with Diaspora organizations, focusing on providing them with the practical knowledge needed to set up micro-finance programmes and initiate women's empowerment campaigns in their home countries. The UK Department for International Development (DFID) assisted about 600 diaspora members' return to their countries of origin to share skills and expertise (ibid).

This programme was run in partnership with the volunteers' service overseas, which was formed with the aim to support Diaspora organizations in planning and implementing their own volunteering programmes in countries of origin. There have been initiatives by DFID to improve remittance transfers and identify investment opportunities for Diaspora groups in the United Kingdom. Thereare some governmental policy suggestions by the Development Research Centre on Migration, Globalization and Poverty; such are measures that policymakers can implement to strengthen relationships with Diasporas who are already mobilized for development purposes. Such are:

- CAPACITY BUILDING: Training programmes with practical skills needed to carry out development projects, or workshops which bring together diaspora organizations to share experiences and expertise.

- BUILDING RELATIONSHIPS: Efforts by country of origin governments to consult with diaspora groups when creating national development plans, or acknowledgement of the contributions of diaspora to development. This would improve partnership for development through improved communication.

- PROTECTING MIGRANTS: Protection of the current generation of migrants can build trust with Diasporas if done by host and country of origin. This would include providing migrants with consular services and pre-departure training, by country-of-origin. Host countries can ensure that benefits accrued by migrants are transferable if they return home.

Source: Diaspora and Development: Building Transnational Partnerships, Briefing from the Development Research Centre on Migration, Globalization and Poverty, Briefing No 19 August 2009. 


\section{CONCLUSION}

The nexus between globalization and the Diaspora is made more important in this era of interchange. Globalized advantages of technology has impacted the contributions of Diaspora to locality development with intensity of attention focused on remittances spanning socio political and economic remittances which are more popular with financial implications to states and currently focusing on diaspora bonds. In the Nigerian instance however, intensified globalized networking was noticed at the introduction of the worldwide web. Interconnectivity and interchange promoted contact and financial transfers to increase the awareness and increase the opportunity for diaspora intervention advantages. In the light of this, international migration becomes an important resource in assisting development. This paper focused on the relationship between globalization and Diaspora's contributions to National development. It interrogated the accruing advantages brought through globalized interchange to Nigeria's National development.

It is noted however, that the scale, scope and impact of different Diaspora efforts for development will vary by a range of factors, i.e. size of the developing country in question and complexity of the challenges it faces, the input/level of adoption of globalized technological advantages and level of receptivity. In the Nigerian instance it is concluded that globalization has provided good opportunity and promoted the contributions of the Nigerian Diaspora to National Development, albeit with growing intensity.

\section{REFERENCES}

[1] Abimbola, O. et al (2004), "Globalization and Poverty: The Nigerian Experience" unpublished paper presented at the National Conference on Social Problems and Globalization, organized by Department of Sociology and Anthropology OAU, Ile-Ife, 16-17 June, 2004.

[2] Aderanti, A. and Arie, V. (2007), "Migration and Development Challenges and Opportunities for the West African Region" Nigerian Journal of International Affairs Vol. 33, No. 2.

[3] AFFORD (1998),A Survey of African Organizations, London: An Agenda for AFFORDs action.

[4] AFFORD (2000), "Globalization and Development: A Diaspora Dimension", A paper submitted by the African Foundation for Development (AFFORD) to the Department for International Development's White paper on Globalisation and Development. May 2000, London .http://www.oneworld.org/ affordinfo@afford.discom.co.uk Retrieved 17/11/2011

[5] Aguolu, C.O (1989),Libraries, Knowledge and National Development, Inaugural Lecture Series, 88/89 Session. University of Maiduguri, No. 45.

[6] Ajayi, K. (2010), "Crises and Contradictions in Nigeria's Democratization Programme 1986-1993", in OlufemiMimiko (ed) Stebak Printers.

[7] Akanni, C. (2004), Globalization and The Peoples of Africa, Enugu: Fourth Dimension Publishing Ltd.

[8] Ake, C. (1978), Revolutionary Pressures in Africa, London: $2^{\text {nd }}$ Press.

[9] Ake, C. (1981),A Political Economy of Africa, London: Longman.

[10] Ake, C. (1990), "Dimensions of African Crisis", Keynote Address to the Conference on the Economic Crisis in Africa.

[11] Ake, C. (1996),Democracy and Development in Africa, New York: Brookings institution.

[12] Al Ali, Nadje, Black, Richard and Koser, Khalid, (1999), "Mobilization and Participation of Transnational Exile Communities in Post Conflict Reconstruction "Sussex University/Migration Research Unit, University College, London.

[13] Albrow and Martin (1996),The Global Age, State and Society, Beyond Modernity, Cambridge: Polity.

[14] Ayodele, J.B. (2005), "Citizenship and Mobilization for Internal Development" in Agagu and Omotoso (ed) Citizenship Education and Governmental Process, Ibadan: Johnmof Printers Ltd.

[15] Babawale, T. (ed) (2007),The Place of Research and Studies in the Development of Africa and the African Diaspora, Lagos: Concept Publications Ltd.

[16] Boyer, D. and Drache (eds) (1996),States Against Markets: The Limits of Globalization. London: Routeledge.

[17] Brown, R.P.C. (1990), "Some Missing Elements in Sudan's Policy Debate: unrecorded remittances, the parallel Economy, and Capital Exports", in Beyond Adjustment: Sub-Saharan Africa (Ministry of Foreign Affairs, Directorate General for International Cooperation, Project Group Africa) The Hague, Ministry of Foreign Affairs Coop.

[18] ChukwuEmeka, C. (undated), "Reinforcing the Contributions of African Diasporas to Development", Retrieved 17/11/2011http://siteresources.worldbank.org/EXTDECPROSPECTS/Resources/476882-1157 133580628/DfD_ch09.pdf 
[19] Cohen, R. (1997), Global Diasporas: An Introduction, London: UCL Press.

[20] Dennis, G. (1971),The Cruel Choice: A New Concept in the Theory of Development, New York: Atheneum.

[21] Department for Food and ID, Building Peaceful States and Societies 2010 DFID.

[22] Deutsch, K. (1953),Nationalism and Social Communication: An Inquiry into the Fountains of Nationality, Cambridge: MIT Press.

[23] "Diaspora and Development: Building Transnational Partnerships, Briefing from the Development Research Centre on Migration, Globalization and Poverty", Briefing No. 19, August 2009. Sussex Centre for Migration Research Arts C. University of Sussex, Falmer, Brighton BNI 95), United Kingdom.

[24] Dudley, S. (1969), "The Meaning of Development" paper presented at the Eleventh World Conference of the Society for International Development, New Delhi.

[25] Eskor, T. (2000),Background to Globalization, Ibadan: Academic Staff Union of Universities.

[26] Eskor, T. (2001),Delusions of a Popular Paradigm: Essays on Alternative Path to Economic Development, Ibadan: The Nigerian Economic Society.

[27] Fadayomi, T.O. (1996), "Brain Drain and Brain Gain in Africa: Dimensions and Consequences” in A. Adepoju and T. Hammar, International Migration in and from Africa: Dimensions, Challenges and Prospects, Dakar: PHDRA, Stockholm, CEIPO.

[28] Fryer, P. (1984),Staying Power: The History of Black People in Britain, London Pluto.

[29] Gay, H. (1967), "Development Administration in East Africa" A Journal of Administration Overseas, Vol. 6, No. 1, January 1967.

[30] "Globalization and Development: A Diaspora Dimension", submission by the African Foundation for Development (AFFORD) to Department of International Development's white paper on Globalization and Development, May 2000, 54, Camberwell Road, London SES OEN.

[31] Green, C. (1997), "Urbanism, Transnationalism and the Caribbean" in Green C. (ed) Globalization and Survival in the Black Diaspora: The New Urban, Cambridge: Albany State University of New York Press.

[32] Guidry, J.A. et al (1999), Globalizations and Social Movements; in Globalizations and Social Movements: Culture, Power and the Trans National Public Sphere, Ann Arbon: University of Michigan Press.

[33] Guillen, (2001),The Limited of Convergence: Globalization and Organizational Change in Argentina, South Korea and Spain, Princeton NJ: Princeton University Press.

[34] Held, D., McGraw A. et al (1999), Global Transformations: Politics, Economics and Culture, Cambridge: Polity.

[35] Hirst, P. and Thomson (1999), Globalization in Question: The International Economy and the Possibilities of Governance, Cambridge: Polity.

[36] International Development Committee (1999), Fifth Report, Department for International Development: 1999 Departmental Report, London: The Stationary Office, No. 45.

[37] Karl, M. (1984),A Contribution to the Critique of Political Economy, Moscow: Moscow Progress Publishers.

[38] Katako, J.Y. (1971), "Bureaucracy and Nation Building in Africa", The Quarterly Journal of Administration, Institute of Administration, University of Ife, Vol. V, No. 4, July 1971.

[39] Kerk, M.E. and Sikkink, K.K. (1998), Activists Beyond Borders: Advocacy Network in International Politics, New York: Cornell University Press.

[40] Lane, J.E. and Ersson, S. (1997),Comparative Political Economy: A Development Approach, London and Washington: Printer $2^{\text {nd }}$ Edition.

[41] Laura, J. (1999), "The Emergence of Bilateral Diaspora Ethnicity Among Cape Verdeen-Americas", in OkpewhoIsidore, Davies, Boyce et al (eds) The African Diaspora; African Origins and New World Identities, Indiana: Indiana University Press.

[42] Midgeley, J. (997),Social Welfare in Global Context: Thousand Oats,London: Sage Publishers.

[43] Mkandiwire, T. and Soludo C.C. (1999),Our Continent, Our Future; African Perspectives on Structural Adjustment, Dakar: CODESRIA.

[44] "Mobilizing African Diaspora for the Promotion of Peace in Africa".African Diaspora Policy Centre http://www.diaspora-centre.org/DOCS/MobilisingAfricanD.pdf Retrieved 17/11/2011

[45] Mohammed, O.A. (2009), "Globalization and the Prospect for African Development: Some Critical Issues" in Nigerian Forum, NIIA vol. 30 Nos 3-4, April to March.

[46] Nweke, A. (1994), "Ethnic Nationalism and Nation Building in Nigeria" cited in W.A. Fawole (ed) Conference Proceedings of the Nigerian Political Science Association, February 28- March 2, 1994. 
[47] Nwomeh, D. (2005), "Pluralism, Party System and National Integration”, Nigerian Forum NIIA Vol. 26, Nos 9-10, Sept/October 2005.

[48] OECD, Organisation for Economic Cooperation and Development (OECD) 1999.

[49] Ogwu, J. (2002), "The African Union and the Challenge of Development in the $21^{\text {st }}$ Century" Public lecture series No 1, Department of Political Science, University of Ilorin.

[50] Omotola, S. (2004), "The Search for a Stable Governmental System in Nigeria”, NIIA, Nigerian Forum, vol. 25, Nos 9-10 Sept/Oct 2004.

[51] Omotola, S. (2010), "Globalization, New Regionalism and the Challenge of Development in Africa", Africana, A Journal of Ideas on Africa and the African Diaspora Vol. 4, No. 1, African Studies Centre, Boston University USA.

[52] Onimode, B. (1983),Imperialism and Underdevelopment in Nigeria: The Dialectics of Mass Poverty, Ibadan: McMillan.

[53] Onimode, B. (1989),A Political Economy of African Crisis, London: Zed press.

[54] Onimode, B. (2000),Africa in the World of the $21^{\text {st }}$ Century, Ibadan: Ibadan University Press.

[55] Organization for Economic Cooperation and Development, OECD, Do No Harm in State Building 2009, Retrieved 7/8/2011, http://www.oecd.org/countries/rwanda/45582738.pdf.

[56] Ozden, C. and Maurice S. (eds) (2006), International Migration, Remittances and the Brain Drain, New York: World Bank Palgrave Macmillan.

[57] Reja, M. and Enloc C. (1969), "Nation States and State-Nations", International Studies, Quarterly 13, 2 June 1969.

[58] Ruport, E. (1970),From Empire to Nation: The Rise of Self Assertion of Asian and African Peoples, $7^{\text {th }}$ Edition, Boston: Howard University Press.

[59] Rodney, W. (1972), How Europe Underdeveloped Africa, Dar essalaam: Tanzania Publishing House.

[60] Schiff, M. \&Caglar O. (eds) (2007),International Migration, Economic Development and Policy, New York: World Bank/Palgrave Macmillan.

[61] Stalker, P. (2002),Workers Without Frontiers: The Impact of Globalization on International Migration, Geneva: International LabourOrganization.

[62] Sen, A.K. (1990), "Development as Capacity Expansion", in Griffing K. and Knight J. (eds) Human Development and the International Development Strategy for the 1990s, New York: Macmillan

[63] Sen, A.K. (1999),Development as Freedom, Oxford: Oxford University Press.

[64] Spanier, J.W. (1972), Games Nations Play, London: Nelson and Sons.

[65] Steve, V. (1999), "Conceiving and Researching Transnationalism” in Ethnic and Racial Studies, Vol 22, No. 2, University of Oxford.

[66] Strategies for Mobilising the Diaspora for Homeland Development: The Case Studies of Ghana, Nigeria and Senegal; African Diaspora Policy Centre, August 2011, http://www.diaspora-centre.org/ DOCS/2011/2011Strategies\%20for\%20mobilisingDiasporaHome_country_polic.pdf Retrieved 17/11/ 2011

[67] Terhemba, A. (2011), "Looking Beyond Conflict: The Involvement of Tiv Diaspora in Peacebuilding in Nigeria”. Journal of Conflictology, Volume 2, issue 1 2011, ISSN 2013-8857.

[68] "The Role of the Diaspora in Nation Building: Lessons for Fragile and Post-Conflict countries in Africa". Prepared by Fragile States Unit (OSFU), Vice- Presidency operations 11-Sector operations African Development Bank - African Development Fund.

[69] Tijani, A. (2008), "Ethnic Identity and the National Question in Nigeria (1960-1970)",Journal of Issues on African Development Vol 1, 2008.

[70] Tilly, C. (ed) (1975),Western-State Making and Theories of Political Transformation, in the Formation of National State in Western Europe, Princeton, Princeton University Press.

[71] Tilly, C. (2000), Coercion, Capital and European States, AD 900-1990, Malden: Blackwell, 2000, ISBN 155786-067-X.

[72] Todaro, M.P. and Smith, S.C. (2009),Economic Development, London: Pearson Education Ltd.

[73] Todaro, M.P. (1976),International Migration in Developing Countries: A Review of Theory, Geneva: IL

[74] Todaro, M.P. (1989),Economic Development in the Third World. $4^{\text {th }}$ Edition, New York: Longman.

[75] United Nations, (2005), Uncommon Database, Department of Economic and Social Affairs, New York: United Nations.

[76] Van Heer, N. (1998),New Diasporas: The Mass Exodus, Dispersal and Re-groupings of Migrant Communities, Seattle: University of Washington Press. 
[77] World Bank, (2000),Entering the $21^{\text {st }}$ Century: World Development Report 1999/2000, New York: Oxford University Press.

[78] World Bank,(2006), Global Economic Prospect 2006: International Remittances and Migration, Washington, DC: World Bank.

[79] Wright, S. and Brown, F.J.N. (eds) (1987),Africa in World Politics: Changing Perspectives London: Macmillan 1987.

\section{AUTHORS' BIOGRAPHY}

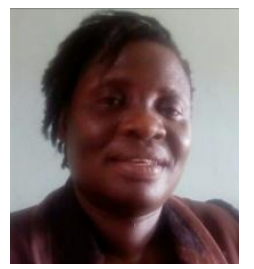

Adu Funmilayo Modupe is a senior lecturer at the Department of History and International Studies, Ekiti State University, Ekiti State.She is a graduate of History from the University of Benin, Benin City. Adu has an MSc and an M.I.R in International Relations from the Obafemi Awolowo University and a $\mathrm{PhD}$ in International Relations from EKSU. Adu has variedly researched into the environment of Migrations, Diaspora Studies, Race and Ethnicity, Conflicts, Gender, Politics, Indigenous Technology and Political Thoughts. She has a growing interest to contribute to solving African and specifically Nigerian development problems.

Citation: Adu, Funmilayo Modupe. "Globalisation and the Diaspora: The Development Dimension in Nigeria”. International Journal of Humanities Social Sciences and Education (IJHSSE), vol 5, no.12, 2018, pp. 86-106. doi:http://dx.doi.org/10.20431/2349-0381.0512010.

Copyright: () 2018 Authors. This is an open-access article distributed under the terms of the Creative Commons Attribution License, which permits unrestricted use, distribution, and reproduction in any medium, provided the original author and source are credited. 